\author{
Anna Czarnowus \\ University of Silesia \\ annaczarnowus@o2.pl
}

\title{
Litanic Tradition in Of on that is so fayr and bright and the Harley Ms Five Joys of Mary ${ }^{1}$
}

\begin{abstract}
This article discusses the influence of Litanies of the Saints on Middle English lyrics, which is exemplified by Of on that is so fayr and bright (New Index No. 2645) and Five Joys of Mary from the Harley Miscellany 2253. The influence of liturgy on Middle English poetry is thus confirmed again. The introductory parts of the poem in the vernacular are interspersed with Latin phrases that must have been taken from litanies, which makes the text a representative of the so-called "litanic verse." Furthermore, events from the Virgin Mary's life are referred to, which is inspired by the Byzantine Great Akathist hymn. The Great Akathist itself also uses diverse Holy Names of Mary. The Harley Five Joys of Mary must have derived from a similar inspiration, since under the form of chanson d'aventure lies the tradition of the Names of Mary, and the listing of the Joys of Mary also suggests the Great Akathist as a source for the lyric. Recent research on litanic verse in various literatures of Europe throughout the ages includes the term "polyonymic," which refers to the many
\end{abstract}

1 The project has been financed by the grant from the National Science Centre in Poland, No DEC-2012/07/E/HS2/00665 [Projekt został sfinansowany ze środków Narodowego Centrum Nauki przyznanych na podstawie decyzji numer DEC$-2012 / 07 / \mathrm{E} / \mathrm{HS} 2 / 00665]$.

I would like to thank the Reviewer for Terminus for all the insightful commentary that allowed me to introduce changes to this article. 
names of God, Jesus, and Mary. The Great Akathist also includes the "chairetismic" element of this type of verse, since Mary is addressed with the word "hail."

Key words: Litanies of the Saints, Middle English lyrics, litanic verse, Great Akathist, Holy Names of Mary.

This article will contribute to the discussion on a large and complex issue, namely to what extent Middle English lyrics were influenced by Litanies of the Saints, which were lists of saints in Latin that did not have a fixed form then ${ }^{2}$. The two tendencies visible in the Middle English tradition, that is interspersing the Names of Mary from litanies in the service books with similar epithets in the vernacular and using the epithets along with resorting to the tradition of the Joys of Mary, will be illustrated with two lyrics. Firstly the macaronic Of on that is so fayr and bright (New Index No. 2645) will be analyzed and then the well-known Five Joys of Mary from the Harley Ms 2253 will be read from the perspective of its litanic epithets and also against the background of the Orthodox Great Akathist hymn, where events from the Virgin Mary's life are narrated.

In her magisterial English Religious Lyric in the Middle Ages Rosemary Woolf divides the poems that praise the Blessed Virgin into three categories. The first subgroup are "those that praise the Virgin and implore her mercy, and that in doing so partly draw on metres and conventions of secular poetry." The second group are "semi-liturgical celebrations of the Virgin's five joys." "The third are lullabies

2 For further discussion of medieval English litanic verse see A. Czarnowus, "That order of apostles is widely honoured by the nations:" Pre-Chaucerian English Poetry, in: Litanic Verse II: Britannia, Germania et Scandinavia, ed. W. Sadowski, M. Kowalska, M.M. Kubas, Frankfurt am Main 2016, pp. 9-30; D. Ruszkiewicz, „Thy name I sall ay nevyne:" Fifteenth-Century England and Scotland, in: Litanic Verse II, pp. 31-50.

3 R. Woolf, The English Religious Lyric in the Middle Ages, Oxford 1968, p. 114.

4 Ibidem. 
that place the Virgin in relation to the Christ-Child. ${ }^{5}$ Woolf identifies the liturgical origin of the poems devoted to the Five Joys, but does not pinpoint the actual source of the Virgin's Names in those text or the original texts that discussed the events from the Virgin's life in a similar manner as the later medieval lyrics. The source of the two elements, epithets and references to Mary's life, are Litanies of the Saints and also the litanic tradition preceding them. The tradition is visible in the so-called Great Akathist, an Orthodox hymn to the Virgin that directly or indirectly inspired the authors of various European literatures to include the Joys of Mary in their poetry.

What needs to be inspected first are the poems earlier than the fourteenth century Joys of Mary lyrics. Of on that is so fayr and bright includes Latin liturgical models, which is not unusual if we note to what extent liturgy pervaded medieval literature and culture. As Bruce Holsinger observes, liturgy had an "amorphously ubiquitous existence in the Middle Ages and in medieval studies." ${ }^{\prime \prime}$ According to Woolf, Of on that is so fayr and bright, a macaronic poem from Ms Trinity 326, provides us with an example of one of "the earliest elaborate poems in praise of the Virgin." She writes about some "Latin sources" that provided inspiration for the lyric, which we can safely identify as Litanies of the Saints. ${ }^{7}$ The lyric in question needs to be seen as belonging to the first category of Marian poetry, even it does not exclusively draw on the tradition of secular love poetry, but also belongs to the corpus of poems that could be termed "litanic verse."

The term "litanic verse" embraces all poetry that has been inspired by Litanies of the Saints and similar liturgical material, since before the establishment of litanies' official texts in the early modern period $^{8}$ those texts were replicated endlessly in different versions, as

5 Ibidem.

6 B. Holsinger, Liturgy, in: Middle English, ed. P. Strohm, Oxford 2007, pp. 295-314.

7 R. Woolf, The English Religious Lyric in the Middle Ages, p. 126.

8 D. Ruszkiewicz, "O Lord, deliver us from trusting in those prayers:" Early Modern England, in: Litanic Verse II: Britannia, Germania et Scandinavia, pp. 51-86. 
already the Anglo-Saxon litanies of the saints in Latin make it clear. ${ }^{9}$ Litanic verse with its repetitive quality was adopted in England once the first litany had been brought to the West by Archbishop Theodore of Canterbury in 668 EC. What characterizes this type of verse are "anaphoric benedictions and greetings, as well as other forms of laudation or acclamation," "supplications and deprecations," and "enumerative lists of an individual's titles."10 In the Marian poems in question there appear enumerations of the Virgin's titles. Sadowski terms this the "polyonymic quality" of litanic verse that refers to the many-namedness of the subject. ${ }^{11}$ The "polyonymic" tradition is much older than the Litany of the Saints itself. "Many-namedness" in texts appeared in Egyptian, Judaic, Christian, and Muslim traditions. The complexity of the polyonymic quality manifested itself in periphrases and antonomasias as ways of referring to a divinity, but without repeating the name itself. Ancient cataloguing, to mention only the Babylonian lists of kings and cities, was yet another litanic phenomenon, even though it predated Christianity. It consisted in recording various names. ${ }^{12}$ Yet, this part of the earliest litanic tradition also entered Christian litany, where the names of various saints were listed. Of on that is so fayr thus resorts to the tradition in which God, Mary, and Jesus were to be praised through listing their Holy Names.

What distinguishes this macaronic poem from other lyrics is the fact that it is one of the few poems of the kind from this period in England. Writes Woolf,

9 For the texts of Anglo-Saxon litanies see M. Lapidge, Anglo-Saxon Litanies of the Saints, London 1991.

10 W. Sadowski, Some Necessary Preliminaries, in: Litanic Verse I: Origines, Iberia, Slavia et Europa Media, ed. W. Sadowski, M. Kowalska, M.M. Kubas, Frankfurt am Main 2016, pp. 9-12.

11 W. Sadowski terms the quality that refer to anaphoras "chairetismic" and the supplicatory quality "ektenial;" W. Sadowski, Some Necessary Preliminaries..., pp. 9-12.

12 See Contexts of Scripture, ed. W. Hallo, vol. 1, The Canonical Compositions from the Biblical World, Leiden 1997, pp. 68-70. 
whilst the large bulk of religious poetry in France chiefly consists of poems to the Virgin, England before the revival of secular love literature at the end of the fourteenth century has comparatively few. ${ }^{13}$

Yet, even the English Marian material before the fourteenth century deserves to be read from the perspective of litanic influences on it. After all, already in the corpus of Old English texts litanies of the saints were numerous, whereas Marian devotion had been in existence for a long time. To quote Woolf, "devotion to the Blessed Virgin had already appeared in England in the late Anglo-Saxon period." ${ }^{14}$ On the other hand, the cult of the Virgin underwent only a small transfer to literature before the fourteenth century. As for other religious topics, what Douglas Gray calls "affective" devotion found its reflection in literary texts, but it did not happen with the Marian cult to such a degree before courtly lyrics started to be composed. ${ }^{15}$ Of on that is so fayr and bright represents litanic verse, since it is grounded in this type of liturgical material and Woolf notes this, even though she does not use the word "litany" herself:

Though sentences of prayer are interwoven in these poems, they are largely Marian eulogies, extolling her by her liturgical titles and by the enumeration of her noble qualities and great deeds. ${ }^{16}$

The "noble qualities" are the Holy Names of Mary that may be found in litanies, while the "great deeds" are the events from her life that were included in the Joys of Mary tradition. Therefore "liturgical" means here "litanic." Both of those litanic elements can be found in the macaronic poem.

Here the version from Ms Egerton 613 will be discussed. The macaronic quality of the poem consists itself in inclusion of Latin

13 R. Woolf, The English Religious Lyric in the Middle Ages..., p. 115.

14 Ibidem, p. 116.

15 D. Gray, Themes and Images in the Medieval English Religious Lyric, LondonBoston 1972, p. 18.

16 R. Woolf, The English Religious Lyric in the Middle Ages..., p. 126. 
phrases, many of which are antonomasias taken from litanies of the saints. ${ }^{17}$ These are "uelud maris stella" [like a star of the sea] (Of on that is 2), which is a well-known epithet once distorted from maris stilla, "a sea drop,"18 "felix fecundata" [happily made preganant] (Of on that is 11), "mater honorata" [esteemed mother] (Of on that is 13), "rosa sine spina" [a rose without thorns] (Of on that is 29). These are antonomasias, which are stand-alone phrases that customarily refer to Mary in litanies. In the lyric they are complemented with other phrases that come from the history of humanity: "parens \& puella" [parent and girl] about the Annunciation (Of on that is 4), "eva peccatrice" [sinful Eve] (Of on that is 20) that refers to Mary as the new Eve, and "gratia diuina" [divine grace] (31) as something that enveloped the Virgin. In this version there also appear antonomasias in Middle English: "quene of parays" (Of on that is 33) and "Mayde milde Moder" (Of on that is 35), which strengthens the litanic effect already achieved by the Latin phrases. This shows that the phrases taken from Latin litanies are not mere embellishments of the poem, but rather they are used intentionally and meaningfully. After all, they are complemented with similar phrases in the vernacular, which means that the audience were fully aware of the denotation of the Latin phrases which only had to be complemented with the English ones. This well illustrates the role of litanies of the saints in medieval England. Writes Katherine Zieman:

Liturgy remained a site in which changing textual practices and religious values were integrated in a culture that still conceived of itself as a Christian textual community for whom the performance of sacred texts played a vital role. $^{19}$

17 The line numbers in brackets preceded by the shortened title Of on that is will come from: C. Brown, Lyrics of the XIII Century, Oxford 1932, pp. 26-27.

18 For a discussion of the Latin hymn Ave, maris stella see E. Chrulska, Litanic Verse in Latin, in: Litanic Verse I: Origines, Iberia, Slavia et Europa Media..., pp. 91-126.

19 K. Zieman, Singing the New Song: Literacy and Liturgy in Late Medieval England, Philadelphia 2008, p. x. 
The thirteenth-century macaronic poem is thus a demonstration of the role of litany in the Christian textual community, which must have valued this type of prayer highly, since phrases from it were integrated in poetry. Importantly, both litanies of the saints and Middle English lyrics could be sung, as the phrase "explicit cantus iste" ( $O f$ on that is 46) at the end of the version in Ms Egerton makes it clear. That was yet another similarity between litany as liturgical material that was to be melodiously recited or even sung and litanic verse that sprang from it.

What is striking in the poem is that the first part, modeled on the litanic tradition of listing names, is followed by the last stanza, which alludes to the Joys of Mary, which means that the first and the second type of Woolf's classification are interspersed here. The Joys are summarized here as:

Wel he wot he is pi sone uentre quem portasi

He wyl not werne pe pi bone paruum quem lactasti.

So hende and so god he his

He hauet brout ous to blis superni;

Pat hauet he-dut he foule put inferni.

(Of on that is 37-45)

What this stanza refers to are the events of the Virgin carrying Jesus in her womb as a result of the Annunciation, breast-feeding him after the Nativity, and the Resurrection that brought humans bliss and combated Satan. This is the shortened version of the Five Joys, which in the Middle English culture were the Annunciation, the Nativity, the Resurrection, the Ascension of Mary, and the Assumption. ${ }^{20}$ Also here the Joys illustrate Mary's relationship with

20 Middle English Literature, ed. Ch.W. Dunn, E.T. Byrnes, New York-London 1990, p. 205. 
Christ ${ }^{21}$ but at the same time they are grounded in the litanic tradition of the Byzantine Great Akathist.

The Great Akathist is an Orthodox hymn in praise of the Virgin. The praise it includes already makes it a text that belongs to the litanic tradition with its division into the rejoicing, supplicatory, and many-namedness as subcategories. What also makes it litanic are its anaphoric structures, which entail praise directed to the Virgin. She is described by her many names:

Hail! sinful Adam's recalling.

Hail! Eve's tears redeeming.

Hail! height untrodden by throught of men.

Hail! depth unscanned by angels ken. ${ }^{22}$

This is one of the texts that established the tradition known as the "hail" lyrics. ${ }^{23}$ Importantly, like the macaronic lyric above, it includes a reference to Eve's sin, which denotes that this Byzantine tradition must have been the primary source for the Joys of Mary poems, since the usual characterization of the Virgin in litanic verse is that of the new Eve. What allows us to establish a similarity are the events from Mary's life that follow the "hail" passages in the Great Akathist. They discuss the role of the Virgin in Jesus's life. In the Great Akathist in praise of the Blessed Virgin in question the respective events are the Annunciation, the apocryphal visitation of Elizabeth, the Nativity, the Epiphany, the encounter with Symeon, and the Resurrection. This shows that the set of events from Mary's life was not taken directly from the Great Akathist, but the idea of hailing her and ad-

${ }^{21}$ S.A. Weber, Theology and Poetry in the Middle English Lyric: A Study of Sacred History and Aesthetic Form, Columbus, Ohio 1969, p. 150.

22 Ode in Honour of the Holy Immaculate Most Blessed Glorious Lady Mother of God and Ever Virgin Mary, transl. by V. McNabb, Oxford 1907, p. 1.

${ }^{23}$ In "'O Lord, deliver us from trusting in those prayers': Early Modern England" Dominika Ruszkiewicz treats the "hail" lyrics as a distinct category; see D. Ruszkiewicz, 'O Lord, deliver us from trusting in those prayers:' Early Modern England...," pp. 51-86. 
dressing her in reference to her relationship with Jesus was a very early one and the later litanic verse only took it up from the already extant liturgical texts.

The discussion here may be complemented with providing a litanic context for The Five Joys of Mary from the fourteenth-century Harley Miscellany, which, as Dunn and Byrnes note, is "neither the oldest nor the most extensive of these poems." ${ }^{24}$ What makes it similar to Of on that is so bright and fayr is that it combines Woolf's first and second type of Marian lyrics, but it does so in a manner which is more obvious. To quote Dunn and Byrnes, "it is certainly the most striking [lyric] because of the compelling way in which it moves from the secular tone of the chanson diaventure [...] to its devout religious purpose." ${ }^{25}$ Gray refers to it as "the characteristic opening of the chanson daventure, which is used or accepted by the best lyrics with a remarkable boldness and imagination."26 In this manner The Five Joys gives us the impression of referring to a courtly lady whom the speaker met in the woods only to redirect our attention to its devout purpose at the end of the second stanza:

Ase I me rod this ender day,

By grene wode to seche play,

Mid herte I thoughte all on a may,

Swetest of alle thinge.

Lithe, and ich ou telle may

All of that swete thinge.

This maiden is swete and fre of blod,

Bright and fair, of milde mod;

Alle he may don us god,

Thurh hire besechinge.

${ }^{24}$ Middle English Literature..., p. 205.

25 Ibidem.

26 D. Gray, Themes and Images in the Medieval English Religious Lyric..., p. 62. 
Of hire he tok flesh and blod, Jesus, Hevene Kinge.

$$
\text { (Five Joys } 1-12)^{27}
$$

Nevertheless, already the first stanza subtly suggests the litanic content of what follows. On the one hand, the setting is discussed as the one for a reverdie, since springtime provides a context for the potentially amorous encounter. On the other, the month of May is described as "swetest of alle thinge," which is an antonomasia similar to those in litanic verse. To boot, the antonomasia is repeated with the statement that the speaker may tell his audience "all of that swete thinge." The antonomasia is thus turned into the statement that the lady encountered in the woods is also a sweet thing. Thus the poem bridges the lyrical situation at the beginning, that of meeting a fair lady, with the religious message of what follows. The beginning of the poem may be read as an entertaining introduction to the ensuing serious religious content.

The second stanza describes the lady as the one of whom "tok flesh and blod, / Jesus, Hevene Kinge," hence it turns out that the initial epithets that gave us the impression of referring to a living woman, "swete and fre of blod, / Bright and fair, of milde mod," as a matter of fact described the Virgin Mary. They are epithets that the two traditions, that of the courtly lyric and the litanic one, shared. Even if "swete" implies love and "fre of blod" aristocratic pedigree, "bright and fair" may just as well apply to the Blessed Virgin, especially if we remember the oft-used even if mistakenly coined antonomasia maris stella, a star of the sea, that also implies lucidity and brightness.

After the antonomasias of the second stanza, which are complemented by the equally ambiguous "of milde mod," since mildness was attributed both to a courtly beloved and to the Virgin in litanic

27 The Five Joys of Mary, ed. R.T. Davies, in: Medieval English Lyrics. A Critical Anthology, ed. R.T. Davies, London 1963, pp. 78-80; the numbers of the lines preceded by the shortened title Five Joys will refer to this edition. 
tradition, there is stanza three that reverses the conventions of the courtly lyric and again multiplies epithets:

With all my lif i love that may:

He is my solas night and day,

My joye and eke my beste play,

And eke my love-longinge.

All the betere me is that day

That ich of hire singe.

Of alle thinge I love hire mest,

My dayes blis, my nightes rest;

He counseileth and helpeth best

Bothe elde and yinge.

Now I may, yef I wole,

The fif joyes minge.

(Five Joys 13-24)

The author humourously reverses the courtly love conventions that can be found in secular love lyrics. While love for a courtly lady does not bring "solas night and day," since it is customarily a source of unrest and anxiety, the word "joye" here is applicable both to the lady and to the Blessed Virgin due to the Joys of Mary tradition. "Love-longinge" is misleading, since it refers to medieval discourse on love, as well as the antonomasia "my dayes blis, my nightes rest," which playfully argues that this love is different since it allows to experience just bliss and no internal tremor during the day and lets the lover sleep well at night. This is all very much unlike what courtly lovers go through when they love a lady. Yet, such a condition is justifiable when the council and help of the Virgin is evoked, which makes her the opposite of the aloof and distanced courtly lady, who will never aid the lover or bring him succor.

A eulogy of the Virgin follows in the discussion of her Joys. Woolf notes that

there was $[\ldots]$ a further way of eulogizing the Blessed Virgin, that of praising her through an enumeration of her five joys, one of the earliest of for- 
malized meditative exercises, and probably the first to be embodied in the Middle English lyrics [emphasis mine, A.C.]..$^{28}$

The Virgin could then be praised in the strictly litanic "hail" lyrics or in the praise expressed through discussing her joys, which had the litanic Great Akathist as its source. Meditating on the events of her life is here called a formalized meditative exercise, which strengthens the impression of this tradition being litanic, since litany was also used for meditative purposes. The repetitive nature of litany's epithets, antonomasias, anaphoras, and epiphoras gave good grounds for meditation, ${ }^{29}$ while not only litanies could be sung, but also litanic verse appeared in the form of songs. ${ }^{30}$ What is only striking is that the devotion of the Joys of Mary entered Middle English literature so late, since, to quote Sarah Appleton Weber,

the devotion of the five joys of Mary - the annunciation and the birth of Christ, His resurrection, His ascension, and Mary's assumption to heaven was popular in England by the time the first poems appeared in the English tongue after the Conquest, and it continued to be so through the fifteenth century. ${ }^{31}$

The meditative practices came first and poetry followed, but it could only occur when the French lyrics started to influence poetry in England, which happened in the fourteenth century. Woolf writes about the Harley lyrics that

Since praise of the lady's beauty was one of the chief themes in trouvère verse, the Harley secular lyrics, which were modelled upon them, developed

28 R. Woolf, The English Religious Lyric in the Middle Ages..., p. 134.

29 W. Sadowski, Some Necessary Preliminaries..., pp. 9-12.

30 Marta Piłat-Zuzankiewicz pinpoints the Castilian autos sacramentales, for instance those that Calderón wrote, as texts where "litanic supplicatory singing" is used; see M. Piłat-Zuzankiewicz, Castilian Poetry and Autos Sacramentales during the Sixteenth and Seventeenth Centuries, in: Litanic Verse I: Origines, Iberia, Slavia et Europa Media..., pp. 143-156.

31 S.A. Weber, Theology and Poetry in the Middle English Lyric..., p. 152. 
a conventional vocabulary of adjectives to describe feminine beauty, and this the Marian lyric[s] draw upon. But the idea of the Virgin's beauty had authoritative foundation in the Song of Songs. ${ }^{32}$

Importantly, some Harley lyrics combine the epithets referring to beauty from the French poetry with the religious purpose, and this is the function of the phrases that the Five Joys of Mary includes.

The lyric departs from the usual pattern of the Joys of Mary since here they are the Annunciation, the Nativity, the Epiphany (not referred to in the other Middle English meters), the Resurrection, and the Ascension of Mary; the Assumption, which is handled separately in the other Middle English treatments, is subsumed under the Ascension. ${ }^{33}$

Weber comments on this that "the number of Mary's joys celebrated varied widely, in English the tradition of five was the most common." ${ }^{34}$ However, she notes that "there was a strong devotion to Mary's seven celestial joys" and that to the fifteen joys as well. ${ }^{35}$ Carleton Brown identifies the version of seven or as many as fifteen joys as continental and treats the number of five joys as a Middle English modification of the French subject. ${ }^{36}$

This is how the Harley Five Joys of Mary specifies those events: "the furst joye of that wimman, / When Gabriel from Hevene cam" (Five Joys 25-26), "that other joye of that may / Wes o Christesmasse day" (Five Joys 31-32), "the thridde joye of that levedy, / That men clepeth the Epiphany" (Five Joys 37-38), "the furthe joye we telle mawen, / On Estermorewe" (Five Joys 43-44), "the fifte joye of that wimman, / When hire body to Hevene cam" (Five Joys 49-50). This

32 R. Woolf, The English Religious Lyric in the Middle Ages..., p. 125.

33 Middle English Literature..., p. 205.

34 A. Wilmart, O.S.B., Auteurs spirituels et textes dévots du moyen âge latin, études d'histoire littéraire, quoted in: S.A. Weber, Theology and Poetry in the Middle English Lyric..., p. 152.

35 S.A. Weber, Theology and Poetry in the Middle English Lyric..., p. 252.

36 English Lyrics of the XIII Century, ed. C. Brown, Oxford 1932, p. 179. 
part of the lyric refrains from interspersing the events from Mary's life with epithets or antonomasias that customarily refer to her both in litanies and litanic verse, but the part is litanic enough when we identify the Great Akathist as the source of the tradition. What this and similar lyrics do is to define "the past joys of Mary's eternal present in order to address her," while the litanic many-namedness at the beginning results from the reality in which "his words transform the events in timeless names of Mary." ${ }^{37}$ Weber writes this in reference to yet another lyric including the Joys of Mary, Glade us maiden, moder milde, whereas in the Harley Five Joys lyric the situation is reversed, since the epithets and antonomasias are followed by the listing and discussion of the events. Hence the Harley author commences with the presence, where the timeless Names of Mary are applicable to her on the speaker's first meeting her, while this timelessness is explained by referring to Mary's past. The third litanic element is the supplication that ends the poem:

Preye we alle to oure Levedy,

And to the sontes that woneth hire by,

That he of us haven mercy,

And that we ne misse

In this world to ben holy,

And winne Hevene blisse.

Amen

(Five Joys 55-61)

The litanic context demonstrates that the Joys of Mary tradition was thus not only "a poetic elaboration upon the mnemonic device of the numerical list," as Christiania Whitehead comments on it, but derived from the litany-inspired listing of divine names and from listing of the events from Mary's life in the Great Akathist hymn. ${ }^{38}$ Listing names in Christianity had a rich theological background, to

37 S.A. Weber, Theology and Poetry in the Middle English Lyric..., p. 157.

38 C. Whitehead, Middle English Religious Lyrics, in: A Companion to the Middle English Lyric, ed. T.G. Duncan, Cambridge 2005, pp. 96-119. 
mention only Dionysius the Areopagite's Divine Names, where God is referred to by multiple antonomasias. ${ }^{39}$ In Dionysius' text the Holy Names of God appear as a part of apophatic theology, which claims that it is easier to say what God is not than to define what He is. Periphrases and antonomasias appear to be indispensable in referring to God indirectly. Furthermore, the range of litanic influence in the Joys of Mary lyrics, here also in the form of the Great Akathist influence, is to be admired.

In the thirteenth, fourteenth, and fifteenth centuries at least four hundred titles of poems written about the Virgin Mary were written in England and the Joys of Mary was one type of them..$^{40}$ The Marian lyrics were very often of litanic provenance, as the example of $O f$ on that is so fayr and bright and the Harley Five Joys of Mary demonstrates. They both include the titles of Mary that can be situated within the Holy Names tradition. Of on that is so fayr alludes to the Joys of Mary, while the topic is treated in full length in The Five Joys of Mary. Even if Holsinger writes that "the particular character of [liturgy's] inherence in so many medieval cultural forms can be difficult to specify," it is not impossible to do in the case of the Marian poems that belong to the group called litanic verse. ${ }^{41}$ There liturgy pervades poetry and Litanies of the Saints become an important inspiration for poets. The audiences must have recognized this source and treated it as important, since litanies were parts of service books at the time.

39 See Dionysius the Aeropagite, Divine Names, transl. C.E. Rolt, Mineola, NY 2012.

40 Sister M.A. Knowlton, The Influence of Richard Rolle and of Julian of Norwich on the Middle English Lyrics, The Hague-Paris 1973, p. 143.

41 B. Holsinger, "Liturgy," pp. 295-314. 


\section{References}

Brown C., Lyrics of the XIII Century, Oxford 1932.

Chrulska E., Litanic Verse in Latin, in: Litanic Verse I: Origines, Iberia, Slavia et Europa Media, ed. W. Sadowski, M. Kowalska, M.M. Kubas, Frankfurt am Main 2016, pp. 91-126.

Contexts of Scripture, vol. 1, The Canonical Compositions from the Biblical World, ed. W. Hallo, Leiden 1997, pp. 68-70.

Czarnowus A., "That order of apostles is widely honoured by the nations:" PreChaucerian English Poetry, in: Litanic Verse II: Britannia, Germania et Scandinavia, ed. W. Sadowski, M. Kowalska, M.M. Kubas, Frankfurt am Main 2016, pp. 9-30.

Dionysius the Aeropagite, Divine Names, transl. C.E. Rolt, Mineola, NY 2012.

Gray D., Themes and Images in the Medieval English Religious Lyric, London-Boston 1972.

Holsinger B., Liturgy, in: Middle English, ed. Paul Strohm, Oxford 2007, pp. 295-314.

Knowlton M.A., Sister, The Influence of Richard Rolle and of Julian of Norwich on the Middle English Lyrics, The Hague-Paris 1973.

Lapidge M., Anglo-Saxon Litanies of the Saints, London 1991.

Medieval English Lyrics. A Critical Anthology, ed. R.T. Davies, London 1963.

Middle English Literature, ed. Ch.W. Dunn, E.T. Byrnes, New York-London 1990.

Ode in Honour of the Holy Immaculate Most Blessed Glorious Lady Mother of God and Ever Virgin Mary, transl. V. McNabb, Oxford 1907.

Piłat-Zuzankiewicz M., Castilian Poetry and Autos Sacramentales during the Sixteenth and Seventeenth Centuries, in: Litanic Verse I: Origines, Iberia, Slavia et Europa Media, ed. W. Sadowski, M. Kowalska, M.M. Kubas, Frankfurt am Main 2016, pp. 143-156.

Ruszkiewicz D., "O Lord, deliver us from trusting in those prayers:" Early Modern England, in: Litanic Verse II: Britannia, Germania et Scandinavia, ed. W. Sadowski, M. Kowalska, M.M. Kubas, Frankfurt am Main 2016, pp. 51-86.

Ruszkiewicz D., “Thy name I sall ay nevyne:” Fifteenth-Century England and Scotland, in: Litanic Verse II: Britannia, Germania et Scandinavia, ed. W. Sadowski, M. Kowalska, M.M. Kubas, Frankfurt am Main 2016, pp. 31-50.

Sadowski W., Some Necessary Preliminaries, in: Litanic Verse I: Origines, Iberia, Slavia et Europa Media, ed. W. Sadowski, M. Kowalska, M.M. Kubas, Frankfurt am Main 2016, pp. 9-12.

Whitehead C., Middle English Religious Lyrics, in: A Companion to the Middle English Lyric, ed. T.G. Duncan, Cambridge 2005, pp. 96-119.

Woolf R., The English Religious Lyric in the Middle Ages, Oxford 1968.

Zieman K., Singing the New Song: Literacy and Liturgy in Late Medieval England, Philadelphia 2008. 